\title{
Peningkatan Keterampilan Berbicara Siswa Melalui Model Role Playing Berbantuan Media Visual di Sekolah Dasar
}

\author{
Livia Istiqomah, Murtono, Fina Fakhriyah \\ PGSD FKIP Universitas Muria Kudus, Jalan Gondang Manis, Kec Bae, Kabupaten Kudus \\ Correspondence Email: 201633161@std.umk.ac.id
}

\begin{abstract}
This research aims to improve student's speaking skills through role playing models assisted by visual media in fifth grade elementary school students the even semester of 2019/2020. This research is a classroom action research 9 CAR) conducted in two cycles using role playing models as a learning method and visual media as learning media. Research data were collected using non test techniques (interviews, observation, and documentation). Data from observations were analysed descriptively quantitative. The results of observations of students' speaking skills at the pre cycle stage consisted of a score of less $(79,41 \%)$ and sufficient (20,58\%). The results of the observation score category of speaking skills of students in the first cycle consisted of less $(8,82 \%)$, sufficient $(52,94 \%)$, good $(8,82 \%)$, with students achieving completeness learning (91,17\%). The results of the cycle II category consisted of good scores $(85,29 \%)$, and very good scores $(14,70 \%)$ with students achieving mastery learning by (99,99\%). Thus the role playing model assisted by visual media is proven to be able to improve students' speaking skills.

Keywords:

Student speaking skills; role playing models; visual media
\end{abstract}

\begin{abstract}
Abstrak
Penelitian ini bertujuan untuk meningkatkan keterampilan berbicara siswa melalui model Role Playing berbantuan media visual siswa Sekolah Dasar pada semester Genap Tahun Pelajaran 2019/2020. Penelitian ini adalah Penelitian Tindakan Kelas (PTK) yang dilaksanakan dalam 2 siklus dengan menggunakan Role Playing sebagai metode pembelajaran dan media visual sebagai media pembelajaran. Data penelitian dikumpulkan menggunakan teknik non tes (wawancara, observasi, dan dokumentasi). Data dari hasil observasi dianalisis secara deskriptif kuantitatif. Hasil kategori skor pengamatan keterampilan berbicara siswa pada tahap pra siklus terdiri dari skor kurang $(79,41 \%)$ dan cukup $(20,58 \%)$. Hasil kategori skor pengamatan keterampilan berbicara siswa pada siklus I terdiri dari kurang $(8,82 \%)$, cukup $(52,94 \%)$, baik $(29,41 \%)$, dan sangat baik $(8,82 \%)$, dengan siswa mencapai ketuntasan belajar sebesar (91,17\%). Hasil kategori siklus II terdiri dari skor baik $(85,29 \%)$, dan skor sangat baik $(14,70 \%)$ dengan siswa mencapai ketuntasan belajar sebesar (100\%). Dengan demikian model Role Playing berbantuan media visual terbukti mampu meningkatkan keterampilan berbicara siswa.
\end{abstract}

\section{Kata Kunci:}

Keterampilan berbicara siswa; model role playing; media visual

\section{Pendahuluan}

Pembelajaran berbahasa sangatlah penting diterapkan, terutama bagi siswa Sekolah Dasar. Berbahasa merupakan sistem simbol yang teratur untuk mentransfer berbagai ide maupun informasi yang terdiri simbol-simbol visual maupun verbal (Setyawan, 2016).
Terdapat empat aspek dalam berbahasa yaitu mendengarkan, berbicara, membaca, dan menulis. Penguasaan aspek-aspek tersebut memiliki tantangan dan kendala sendiri bagi siswa. Dari keempat aspek berbahasa, salah satu aspek berbahasa yang sering menjadi momok bagi siswa adalah keterampilan 
berbicara. Hal tersebut dikarenakan berbicara merupakan aktivitas yang sulit, tidak sekedar mengeluarkan kata dan bunyi-bunyi, melainkan penyusunan gagasan yang dikembangkan sesuai dengan pendengar atau penyimak (Putra, 2016).

Di SD (Sekolah Dasar) keterampilan berbicara sangat diperlukan dalam kegiatan belajar mengajar, dikarenakan berbicara tidak lepas dari aspek menyimak dan membaca. Dengan menguasai aspek keterampilan berbicara maka siswa, dapat mengekspresikan pikiran dan perasaan sesuai dengan konteks pembicaraan selama proses pembelajaran berlangsung. Kegiatan belajar mengajar yang sering dijumpai di sekolah adalah kegiatan belajar yang diterapkan oleh guru masih menggunakan metode pendekatan pembelajaran konvensional. Pendekatan pembelajaran konvensional dapat mengakibatkan rendahnya keterampilan berbicara siswa, hal tersebut dipicu karena pembelajaran konvensional berlangsung secara monoton dan membosankan sehingga menyebabkan siswa pasif dan cenderung diam saja selama proses pembelajaran.

Hal tersebut sama dengan kondisi siswa di Sekolah Dasar. Berdasarkan hasil observasi ditemukan beberapa masalah saat proses pembelajaran berlangsung yaitu guru masih menggunakan metode konvensional sehingga mengurangi minat siswa dalam belajar siswa, selain itu siswa yang menguasai ranah pengetahuan khususnya pada materi menceritakan pengamatan secara lisan masih rendah. Hal tersebut terjadi karena siswa merasa takut dan ragu-ragu dalam mengemukakan pendapat di dalam kelas, sehingga ketepatan penggunaan bahasa masih rendah dan kurang, siswa belum mampu dalam menyusun kata-kata yang runtut. Kebiasaan inilah yang mengakibatkan keterampilan berbicara siswa Sekolah Dasar masih rendah dan belum maksimal. Dari keseluruhan 34 siswa, hanya $21 \%$ atau 7 siswa saja yang dapat mencapai Kriteria Ketuntasan Minimal (KKM) yang telah ditetapkan di Sekolah Dasar yaitu $\geq 70$. Terkadang kondisi tersebut juga diperparah dengan penggunaan media pembelajaran yang digunakan guru dalam menyampaikan materi kurang menarik, sehingga minat siswa dalam belajar renda

Antusiasme belajar yang rendah diduga menjadi penyebab rendahnya keterampilan berbicara siswa dalam pembelajaran. Metode pembelajaran yang tepat, sangat diperlukan untuk meningkatkan hasil belajar dan motivasi siswa, khususnya dalam meningkatkan keterampilan berbicara siswa. Metode konvensional seperti ceramah dan menghafal membuat siswa merasa jenuh dan malas memperhatikan. Metode ceramah cenderung membuat siswa menjadi pasif di dalam kelas sehingga siswa kurang mendapat kesempatan untuk mengemukakan pendapat dan menjadikan pembelajaran hanya berjalan satu arah yaitu dari guru kepada siswa, dimana siswa hanya sebagai penerima ilmu dan guru sebagai sumber belajar. Meskipun demikian metode ceramah dapat diterapkan ketika siswa benar-benar memerlukan penjelasan.

Suasana kelas yang menyenangkan dan pengelolaan kelas yang efektif serta menarik, mendorong siswa untuk dapat mengemukakan ekspresi dan pendapat dengan leluasa, sehingga memunculkan antusiasme siswa dalam belajar. Guru hanya berperan sebagai fasilitator untuk mengarahkan dan memotivasi siswa, sehingga siswa berani mengemukakan gagasan, bertanya ketika ada materi yang belum dipahami oleh siswa. Dengan begitu penggunaan model pembelajaran dan media pembelajaran dirasa baik untuk 
menciptakan suasana kelas yang aktif selama proses pembelajaran berlangsung.

Model Role Playing dapat meningkatkan keterampilan berbicara siswa, hal tersebut dikarenakan model Role Playing merupakan bentuk pendekatan pembelajaran yang menekankan keaktifan siswa selama proses pembelajaran berlangsung. Dengan menggunakan model Role Playing, guru dapat meningkatkan gairah dan semangat siswa dalam belajar berbicara, selain itu siswa juga tidak akan merasa malu untuk berbicara khususnya bermain peran, siswa juga akan mudah mengerti materi yang sedang dibahas dengan menggunakan metode atau teknik Role Playing (Devi, et al., 2015).

Interaksi guru dan siswa bukan hanya diperlancar dengan menggunakan model pembelajaran saja, tetapi juga perlu diperlancar dengan adanya sebuah media pembelajaran yang yang menarik. Media pembelajaran yang menarik sangat penting diperlukan guna menunjang keaktifan siswa khususnya dalam meningkatkan keterampilan berbicara siswa selama pembelajaran. Media pembelajaran adalah alat yang dapat membantu proses belajar mengajar sehingga makna pesan yang disampaikan menjadi lebih jelas dan tujuan pendidikan atau pembelajaran dapat tercapai dengan efektif dan efisien (Nurrita, 2018). Media pembelajaran dapat dibedakan menjadi delapan klasifikasi media yaitu, (1) media audio visual gerak, (2) media audio visual diam, (3) media audio semi gerak, (4) media visual gerak, (5) media visual diam, (6) media visual semi gerak, (7) media audio, (8) media cetak (Tafonao, 2018). Dari delapan klasifikasi media pembelajaran yang sudah disebutkan tidak semua sekolah memiliki kemampuan untuk menyediakan semua media pembelajaran. Salah satu media pembelajaran sederhana yang dapat digunakan oleh guru, adalah media visual. Media visual adalah media pembelajaran yang penyampaiannya melalui indra pandang dan penglihatan yang dapat dituangkan ke dalam berbagai bentuk gambar, sketsa, atau grafis. Dengan penggunaan media visual siswa dapat memperkuat ingatan, menumbuhkan minat siswa dan dapat memberikan hubungan antara isi materi pelajaran dengan dunia nyata (Arsyad, 2016). Namun, media pembelajaran visual yang sering dijumpai di kelas adalah gambar yang biasanya ditempel di dinding kelas. Pemanfaatan media pembelajaran visual sederhana berupa kartu flashcard dirasa mampu untuk meningkatkan keterampilan berbicara siswa. Media pembelajaran visual diketahui dapat meningkatkan hasil belajar siswa, hal ini dikarenakan di dalam media visual siswa dapat melihat materi yang disampaikan secara langsung sehingga materi tersebut lebih mudah ditangkap serta dipahami oleh siswa. Penggunaan media visual dimaksudkan supaya siswa terdorong untuk aktif selama proses kegiatan belajar.

Penelitian ini bertujuan untuk meningkatkan keterampilan berbicara siswa melalui model pembelajaran Role Playing berbantuan media Visual pada siswa Sekolah Dasar Semester Genap Tahun Pelajaran 2019/2020. Dari hasil pengamatan selama proses pembelajaran berlangsung keterampilan berbicara siswa di Sekolah Dasar pada semester Genap Tahun Pelajaran 2019/2020 menunjukkan kategori rata-rata nilai kurang dan terdapat sejumlah siswa yang belum memenuhi Kriteria Ketuntasan Minimal (KKM). Perbaikan dapat dilakukan dengan model penyampaian materi dan penggunaan media pembelajaran. Penerapan model pembelajaran dan media pembelajaran dapat dimaksimalkan guna mendukung efektifitas selama proses 
pembelajaran. Penerapan model Role Playing berbantuan media Visual diharapkan mampu untuk meningkatkan keterampilan berbicara siswa pada siswa Sekolah Dasar.

Penelitian ini merupakan jenis Penelitian Tindakan Kelas (PTK) yang dilaksanakan dalam 2 (dua) siklus. Prasiklus merupakan hasil dari pengamatan selama kegiatan pembelajaran berlangsung dengan metode ceramah dan media pembelajaran konvensional. Siklus I dilakukan dengan menggunakan model pembelajaran Role Playing berbantuan media visual dengan fokus materi bentuk interaksi manusia dengan lingkungan alam. Siklus II dilakukan juga dengan menggunakan model Role Playing berbantuan media visual dengan fokus materi mengidentifikasi aktivitas masyarakat sekitar dalam upaya pembangunan ekonomi, sosial budaya Indonesia. Masing-masing siklus dilaksanakan dalam dua kali pertemuan yang meliputi 4 (empat) tahapan, yaitu (1) perencanaan, (2) pelaksanaan, (3) pengamatan, (4) refleksi. Penelitian tindakan ini dilaksanakan di SD 1 Pladen, kecamatan Jeluko, Kabupaten Kudus. Penelitian dilaksanakan pada Semester Genap Tahun Pelajaran 2019/2020. Subjek penelitian ini adalah seluruh siswa kelas V SD 1 Pladen yang berjumlah 34 siswa. Media visual yang digunakan berupa kartu flashcard. Setiap kelompok mendapatkan 1 (satu) kartu flashcard yang berisi potongan skenario, yang nantinya kartu tersebut digunakan untuk bermain peran.

Bercocok tanam di rumah adalah salah satu hobi keluarga Tono. Tono dan keluarganya melakukannya di depan rumah. Tono dan keluarganya menanam berbagai macam sayur di depan rumah ada kangkung, bayam, tomat dan cabai.

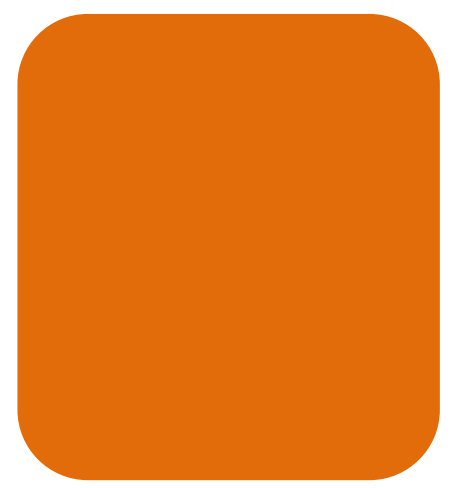

Gambar 1. Media Visual Kartu Flashcard.

Data dikumpulkan menggunakan teknik non tes. Teknik non tes meliputi wawancara, observasi, dan dokumentasi. Observasi dilakukan untuk mengukur keterampilan berbicara siswa selama diterapkannya model Role Playing berbantuan media Visual. Indikator observasi keterampilan berbicara meliputi, (1) kelancaran berbicara, (2) ketepatan pemilihan kata atau diksi, (3) struktur kalimat, (4) intonasi membaca kalimat, dan (5) ekspresi. Wawancara dilakukan terhadap guru terkait dengan penggunaan model pembelajaran dan media pembelajaran, serta kendala yang dihadapi selama proses pembelajaran. Dokumentasi berupa data siswa yang berisi daftar nama, foto guru dan siswa ketika proses pembelajaran dengan menerapkan model Role Playing berbantuan media visual.

Variabel input yang dipilih adalah siswa Sekolah Dasar. Variabel proses yang ditentukan adalah model Role Playing berbantuan media visual. Variabel output yang diamati berupa peningkatan keterampilan berbicara siswa. Data kuantitatif berupa hasil observasi keterampilan belajar siswa dianalisis menggunakan deskriptif pada kedua siklus, kemudian dikonversi menjadi nilai (antara 1-4). 
Tabel 1. Kategori Nilai Keterampilan Berbicara Siswa

\begin{tabular}{cc}
\hline Kategori & Rentang Nilai \\
\hline Sangat Baik & $90-100$ \\
Baik & $80-89$ \\
Cukup & $70-79$ \\
Kurang & $<70$ \\
\hline
\end{tabular}

2. Hasil dan Pembahasan

2.1 Hasil

\subsubsection{Tahap Prasiklus}

Data pra siklus diperoleh dari hasil observasi keterampilan berbicara siswa selama kegiatan pembelajaran dengan menggunakan metode ceramah dan media pembelajaran konvensional. Sebagian besar siswa belum menguasai keterampilan berbicara, sehingga hasil observasi keterampilan berbicara siswa yang didapatkan sangatlah rendah yang dapat dilihat pada Tabel 2.

Tabel 2. Hasil Observasi Keterampilan Berbicara Siswa Pra Siklus

\begin{tabular}{ccc}
\hline $\begin{array}{c}\text { Kategori/Rentang } \\
\text { Nilai }\end{array}$ & Frekuensi & Persentase \\
\hline Sangat Baik (90-100) & $\mathrm{o}$ & $\mathrm{0} \%$ \\
Baik (80-89) & $\mathrm{o}$ & $\mathrm{o} \%$ \\
Cukup (70-79) & 7 & $20,58 \%$ \\
Kurang (<70) & 27 & $79,41 \%$ \\
\hline
\end{tabular}

Berdasarkan Tabel 2 di atas dapat disimpulkan bahwa siswa yang berada pada kategori kurang sebanyak 27 siswa dengan persentase sebesar $79,41 \%$. Sedangkan siswa yang berada pada kategori cukup sebanyak 7 siswa, dengan persentase sebesar 20,58\%. Tidak terdapat siswa yang berada dalam kategori baik dan sangat baik. Analisis hasil pengamatan keterampilan berbicara siswa pra siklus Tabel 2 dapat dibuat dalam grafik diagram batang pada Gambar 2.

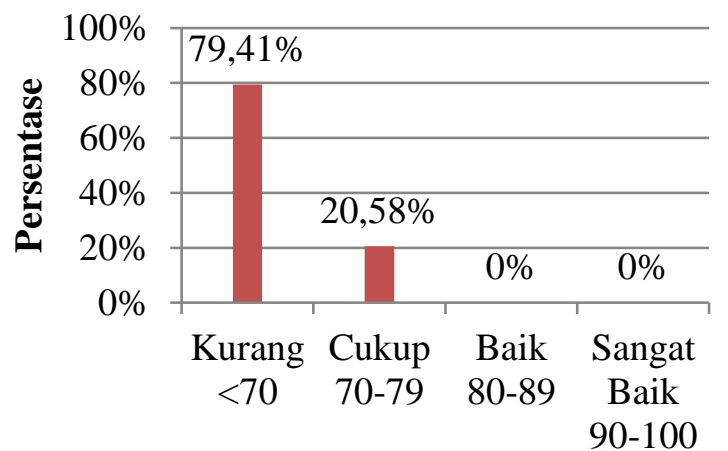

Gambar 2. Diagram hasil observasi keterampilan berbicara siswa pra siklus

Berdasarkan Gambar 2 hasil observasi keterampilan berbicara siswa pra siklus dapat diketahui bahwa masih dalam kategori kurang. Hal tersebut ditunjukkan dengan 79,41\% (27 siswa) yang berada pada kategori kurang, selebihnya 20,58\% (7 siswa) siswa dalam 
kategori cukup. Berdasarkan hasil observasi tersebut, metode ceramah dan penggunaan media konvensional kurang cocok digunakan untuk meningkatkan keterampilan berbicara siswa, karena hanya gurulah yang berperan aktif dalam menguasai kelas, siswa cenderung pasif dan diam saja mendengarkan penjelasan dari guru.

\subsubsection{Tahap Siklus I}

Data siklus I diperoleh dari hasil observasi keterampilan berbicara siswa selama menggunakan model Role Playing berbantuan media visual dengan fokus

materi bentuk interaksi manusia dengan lingkungan alam, yang dapat dilihat pada Tabel 3.

Tabel 3. Hasil Observasi Keterampilan Berbicara Siswa Siklus I

\begin{tabular}{ccc}
\hline Kategori (Rentang & Frekuensi & Persentase \\
Nilai) & 3 & $8,82 \%$ \\
\hline Sangat Baik (90-10o) & 18 & $52,94 \%$ \\
Baik (8o-89) & 10 & $29,41 \%$ \\
Cukup (70-79) & 3 & $8,82 \%$ \\
Kurang $(<70)$ & & \\
\hline
\end{tabular}

Berdasarkan Tabel 3 dapat diketahui bahwa siswa yang berada pada kategori kurang turun menjadi 3 siswa dengan persentase $8,82 \%$. Siswa yang berada pada kategori cukup menjadi 10 siswa dengan persentase $\quad 52,94 \%$ Kemajuan keterampilan berbicara siswa tampak dengan adanya siswa yang berada pada kategori baik sebanyak 18 siswa dengan persentase $29,41 \%$, dan kategori sangat baik sebanyak 3 siswa dengan persentase $8,82 \%$. Analisis hasil pengamatan keterampilan berbicara siswa pada Siklus I pertemuan 1 dan 2 Tabel 3 dapat dibuat dalam diagram batang pada Gambar 3.

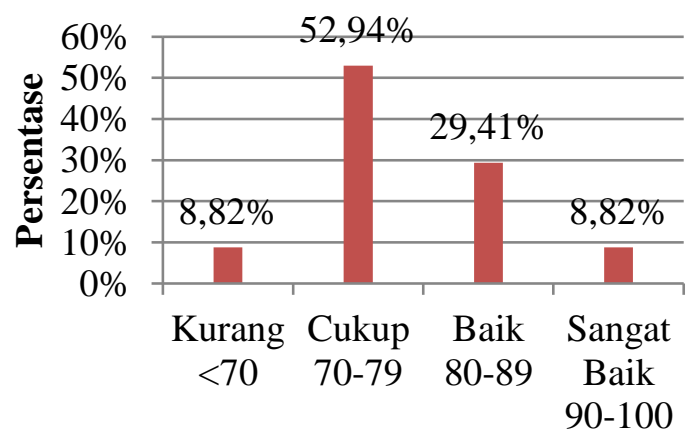

Gambar 3. Hasil Observasi Keterampilan Berbicara Siswa Siklus I

Berdasarkan Gambar 2 hasil observasi keterampilan berbicara siswa pada siklus I mengalami peningkatan dengan ketuntasan belajar klasikal yang dicapai pada Tahap siklus I mulai membaik, yaitu
91,17\% dengan menyisakan $8,82 \%$ siswa yang belum tuntas. Penggunaan model Role Playing berbantuan media visual mampu meningkatkan ketuntasan belajar klasikal. 


\subsubsection{Tahap Siklus II}

Data pada siklus II diperoleh dari hasil observasi keterampilan berbicara siswa dengan menggunakan model Role Playing berbantuan media visual dengan fokus materi mengidentifikasi aktivitas masyarakat sekitar dalam upaya pembangunan ekonomi, sosial budaya Indonesia, yang dapat dilihat pada Tabel 4 .

Tabel 4. Hasil Observasi Keterampilan Berbicara Siswa Siklus II

\begin{tabular}{ccc}
\hline $\begin{array}{c}\text { Kategori (Rentang } \\
\text { Nilai) }\end{array}$ & Frekuensi & Persentase \\
\hline Sangat Baik (90-100) & 29 & o\% \\
Baik (80-89) & 5 & o\% \\
Cukup (70-79) & 0 & $85,29 \%$ \\
Kurang $(<70)$ & o & $14,70 \%$ \\
\hline
\end{tabular}

Dari Tabel 4 dapat diketahui bahwa hasil observasi keterampilan berbicara siswa pada siklus II menunjukkan bahwa tidak terdapat siswa yang berada dalam kategori kurang dan cukup. Sedangkan jumlah siswa yang berada pada kategori baik sebanyak 29 siswa dengan persentase sebesar $85,29 \%$, dan kategori sangat baik sebanyak sebanyak 5 siswa dengan persentase 14,70\%. Analisi hasil pengamatan keterampilan berbicara siswa pada siklus I pertemuan 1 dan 2 Tabel 4 dapat dibuat dalam diagram batang pada Gambar 4.

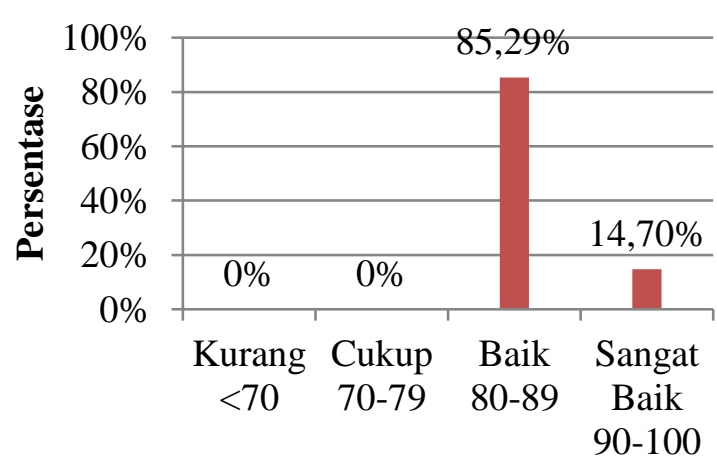

Gambar 4. Hasil Observasi Keterampilan Berbicara Siswa Siklus II

Berdasarkan Gambar 4 hasil observasi keterampilan berbicara siswa pada siklus II dengan menerapkan model Role Playing berbantuan media visual, ketuntasan belajar klasikal sudah mencapai 100\%, sudah tidak ada siswa yang berada dalam kategori cukup dan kategori kurang.

\subsection{Pembahasan}

Pada kondisi pra siklus proses pembelajaran belum menggunakan model
Role Playing berbantuan media visual, sehingga keaktifan siswa dalam keterampilan berbicara selama proses pembelajaran sangat rendah. Model pembelajaran Role Playing merupakan metode pembelajaran yang cara menyajikan bahan pelajaran dengan mempertunjukkan dan mempertontonkan atau mendramatisasikan cara tingkah laku 
dalam hubungan sosial (Taniredja, 2011). Selain itu dengan adanya media bantu visual dalam proses belajar mampu dengan cepat meningkatkan taraf kecerdasan dan mengubah sikap pasif ke arah aktif Herjianto dalam (Putra \& Tuasikal, 2017). Untuk memperbaiki kondisi tersebut, maka kegiatan pembelajaran akan dilakukan dengan menggunakan model Role Playing berbantuan media visual. Pada siklus I hasil observasi keterampilan berbicara siswa mulai ada peningkatan yang signifikan, hal tersebut tampak adanya beberapa siswa yang sudah berkontribusi membantu satu kelompoknya untuk melengkapi potongan skenario pada kartu flashcard yang diberikan oleh. Selain itu beberapa siswa yang awalnya jahil kepada dan mengganggu kelompok lain yang sedang mempersiapkan penampilannya untuk bermain peran sudah mulai terkondisikan dengan baik, sehingga berdampak terhadap keterampilan berbicara siswa.

Pembelajaran pada siklus II dilakukan untuk memperbaiki kekurangan yang ada pada siklus sebelumnya, selama proses pembelajaran siklus II berlangsung dengan menerapkan model Role Playing berbantuan media visual, siswa sudah terbiasa menggunakan model Role Playing berbantuan media visual, hal tersebut dilihat dengan siswa yang sangat antusias dan senang dalam proses pembelajaran, sehingga tujuan pembelajaran tercapai dengan baik sesuai dengan yang diharapkan. Untuk lebih jelasnya peningkatan keterampilan berbicara siswa pada kondisi awal sampai siklus II dapat dilihat pada Tabel 5 .

Tabel 5. Hasil Observasi Keterampilan Berbicara Siswa Dari Prasiklus Sampai Siklus II

\begin{tabular}{cccc}
\hline & \multicolumn{3}{c}{ Kegiatan Pembelajaran } \\
\hline & Prasiklus & Siklus I & Siklus II \\
Tuntas & 7 Siswa & 31 Siswa & 34 Siswa \\
Persentase & $20,58 \%$ & $91,17 \%$ & $100 \%$ \\
Tidak Tuntas & 27 Siswa & 3 Siswa & o \\
Persentase & $79,41 \%$ & $8,82 \%$ & $0 \%$ \\
\hline
\end{tabular}

Berdasarkan Tabel 5 hasil observasi keterampilan berbicara siswa pada pra siklus sebanyak 27 siswa tidak tuntas dengan persentase $79,41 \%$, dan jumlah siswa tuntas sebanyak 7 siswa dengan persentase $20,58 \%$. Pada siklus I jumlah siswa yang tidak tuntas mengalami penurunan yaitu sebanyak 3 siswa tidak tuntas dengan persentase $8,82 \%$, sedangkan siswa tuntas sebanyak 31 siswa dengan persentase 91,17\%. Sedangkan pada siklus II jumlah siswa yang tuntas sebanyak 34 siswa dengan persentase $100 \%$, dan tidak ada siswa yang berada pada kategori tidak tuntas. Analisis hasil pengamatan keterampilan berbicara siswa pada pra siklus sampai siklus II Tabel 5 dapat dibuat dalam diagram batang pada Gambar 5. 


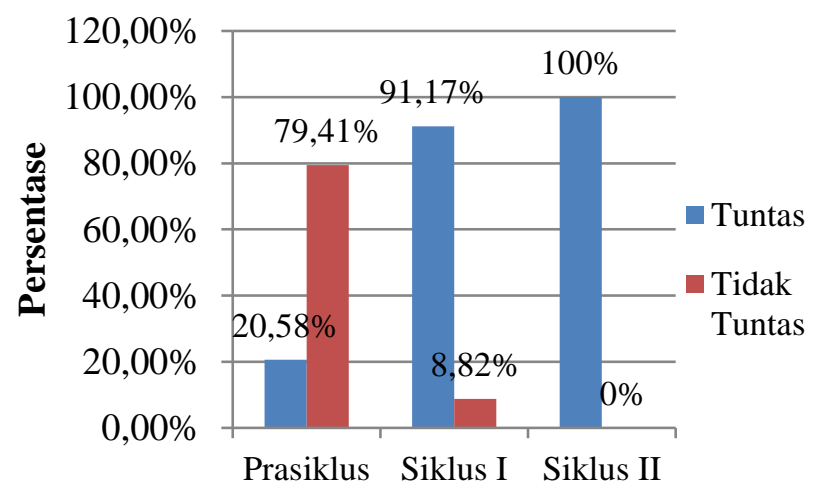

Gambar 5. Hasil Observasi Keterampilan Berbicara Siswa Dari Prasiklus Sampai Siklus

Berdasarkan Gambar 5 di atas dapat disimpulkan bahwa siswa dengan persentase tuntas pada pra siklus 20,58\% , dan siswa dengan persentase tidak tuntas sebesar 79,41\%. Pada siklus I mengalami peningkatan yaitu sebanyak $91,17 \%$ siswa dalam persentase tuntas, dan sebanyak $8,82 \%$ siswa dengan persentase tidak tuntas. Pada kondisi siklus II siswa dengan persentase tuntas sebesar 100\%. Oleh karena itu model pembelajaran dan media pembelajaran yang sesuai dengan karakteristik siswa perlu diterapkan untuk mencapai ketuntasan belajar. Model pembelajaran dan media pembelajaran yang menarik dan efektif memerlukan penggunaan yang tepat. Pemilihan model pembelajaran dan media pembelajaran yang sesuai dengan kebutuhan juga terkadang masih belum menghasilkan hasil yang maksimal, karena penggunaan model pembelajaran dan media pembelajaran tidak diterapkan dengan tepat.

Berdasarkan uraian tersebut maka penerapan model Role Playing berbantuan media visual dapat meningkatkan keterampilan berbicara siswa pada tema Panas dan Perpindahannya siswa kelas V SD 1 Pladen pada Semester Genap Tahun Pelajaran 2019/2020.

Hal ini dikarenakan dengan menerapkan model Role Playing berbantuan media visual siswa dapat diarahkan untuk memahami materi yang disajikan oleh guru dengan cara bermain peran. Selain itu dengan menerapkan model Role Playing berbantuan media visual membantu siswa supaya terlibat aktif dalam pembelajaran sehingga dapat membangun rasa percaya diri di dalam kelas.

Temuan tersebut membuktikan bahwa siswa perlu model pembelajaran yang inovatif, dan menarik bagi siswa, sehingga pembelajaran di kelas menjadi aktif. Berbagai model pembelajaran telah dikembangkan untuk menanggulangi kendala yang dihadapi pada keterampilan berbicara siswa.

Hasil penelitian yang dilakukan memiliki persamaan dan perbedaan dengan penelitian Nurhasanah, Sujana, dan Sudin (2016), penelitian Saputra, Maskun, dan Arif (2017), penelitian Kristin (2018). Adapun persamaannya yaitu pada model pembelajaran Role Playing yang digunakan. Sementara itu perbedaannya pada hasil riset yang dilakukan.

Penelitian Nurhasanah, Sujana, dan Sudin (2016) menyimpulkan bahwa model Role Playing dapat meningkatkan hasil belajar siswa pada materi hubungan makhluk hidup dengan lingkungannya. Sementara itu penelitian Saputra, 
Maskun, dan Arif menyimpulkan bahwa pengaruh model Role Playing dapat meningkatkan motivasi belajar siswa pada pembelajaran IPS di SMP Negeri 2 Pringsewu. Lebih lanjut penelitian Kristin (2018) menyimpulkan bahwa model pembelajaran Role Playing dapat meningkatkan hasil belajar siswa pada materi pelajaran IPS.

\section{Simpulan}

Model pembelajaran Role Playing berbantuan media visual terbukti mampu meningkatkan keterampilan berbicara siswa pada siswa kelas V SD 1 Pladen Semester Genap 2019/2020. Keterampilan berbicara siswa mengalami peningkatan dari rata-rata (mean) nilai prasiklus sebesar 61, meningkat pada siklus I sebesar 8o, dan meningkat lagi pada siklus II sebesar 86. Ketuntasan belajar klasikal mengalami peningkatan dari persentase ketuntasan Prasiklus sebesar 20,58\%, meningkat lagi pada siklus I sebesar 91,17\%, dan meningkat lagi pada siklus II sebesar ${ }_{100 \%} \%$. Implikasi dari penelitian ini bahwa penggunaan model pembelajaran bisa memberikan situasi pembelajaran yang berdampak terhadap peningkatan bagi siswa salah-satunya dalam aspek keterampilan.

\section{Daftar Pustaka}

\section{Buku}

Arsyad, A. (2016). Media Pembelajaran, Jakarta: Rajawali Pers.

Tukiran, T., Miftah, F \& Sri, H. (2011).

Model-Model Pembelajaran,

Bandung: Alfabeta.

\section{Jurnal}

Anggara, W. P. (206). Peningkatan Keterampilan Berbicara Menggunakan Metode Kooperatif Tipe Jigsaw Pada Mahasiswa PBSI Tingkat I-B IKIP PGRI Bojonegoro
Tahun Akademik 2018/2019. Jurnal Kredo, 2 (2).

Elwi, N. M., Nyoman, S. D \& Fattah, H. (2019). Upaya Peningkatan Keterampilan Berbicara Siswa Menggunakan Media Gambar Siswa Kelas V SD. Jurnal Pendidikan, 4 (11).

Farid, H. S. (2016). Meningkatkan Kemampuan Berbahasa Anak Usia Dini Melalui Model Pembelajaran Visual Berbasis Android. Jurnal PG PAUD Trunojoyo, 3 (2), 93.

Firosalia, K. (2018). Meta-Analisis Pengaruh Model Pembelajaran Role Playing Terhadap Hasil Belajar IPS. Jurnal Refleksi Edukatika, 8 (2).

Irene, F. W., Prana, D. I \& Cucun, S. (2017). Upaya Meningkatkan Kemampuan Berbicara Siswa Dalam Menceritakan Peristiwa Yang Dialami Menggunakan Metode Talking Stick Berbantuan Media Gambar Seri. Jurnal Pena Ilmiah, 2 (1).

Ismawati, A. N., Atep, S \& Ali, S. (2016). Penerapan Metode Role Playing Untuk Meningkatkan Hasil Belajar Siswa Pada Materi Hubungan Makhluk Hidup Dengan Lingkungannya. Jurnal Pena Ilmiah, 1 (1).

Maharani, S. D., Wendra, I. W \& Gunatama, G. (2015). Penerapan Metode Role Playing Untuk Meningkatkan Keterampilan Berbicara (Bermain Peran) Pada Siswa Kelas VIII B MTs ALKHAIRIYAH TEGALLINGGAH. eJurnal Jurusan Pendidikan Bahasa dan Sastra Indonesia, 3 (1).

Muklas, S. P \& Abdul, R. S. T. (2017). Pemanfaatan Media Visual Tehadap Hasil Belajar Dribble Bola Basket (Studi Pada Siswa Kelas XII SMALB-B Dharma Wanita 
660 | Naturalistic: Jurnal Kajian Penelitian dan Pendidikan dan Pembelajaran, Volume 5 Issue 1, Oktober 2020 Hal 650-66o

Sidoarjo). Jurnal Pendidikan Olahraga dan Kesehatan, 5 (2).

Sidiq, S., Maskun \& Suparman, A. (2017).

Pengaruh Model Role Playing

Dalam Pembelajaran IPS Terhadap

Peningkatan Motivasi Belajar

Siswa. PESAGI (Jurnal Pendidikan dan Penelitian Sejarah), 5 (3).

Talizaro, T. (2018). Penerapan Media Pembelajaran Dalam Meningkatkan Minat Belajar Mahasiswa. Jurnal Komunikasi Pendidikan, 2 (2), 106.

Teni, N. (2018).Pengembangan Media Pembelajaran Untuk Meningkatkan Hasil Belajar Siswa. Jurnal Misykat, 3 (1), 174. 